\title{
Questioning 'the public': exploring the meanings of public engagement in higher education
}

John Gabriel (London Metropolitan University)

Jennifer Harding (London Metropolitan University)

\begin{abstract}
This article discusses an example of public engagement involving university staff and students, a local charity and older residents in a community oral history project. It is based on participants' oral and written accounts of their involvement. It critically examines the meanings of public, engagement and public good created through the project in relation to neoliberalism. It discusses publics as 'emergent' and various public engagement activities as 'assemblages', formed in particular historical and ideological discursive contexts, and reflects critically on the usefulness of these conceptualisations. It also reviews the operation of a potential counterpublic and its implications.
\end{abstract}

Keywords: Public engagement, emergent publics, assemblage, counterpublic, neoliberalism

\section{Introduction}

This article explores the meanings of public engagement in higher education through reflecting on a community based oral history project involving university staff and students, a local charity and older people living in the London Borough of Islington. It discusses the implications of this particular example of public engagement within the wider neoliberal environment in higher education as well as ways of conceptualising both 'public' and 'engagement'.

The Lost Trades of Islington Project (2017-2019) used oral history interviews to collect older residents' reflections on working life in the second half of the twentieth century (Gabriel and Harding 2020). Subsequently, participants were invited to reflect on their experiences of taking part in the project. In this article, we analyse their spoken and written reflections in order to unpack and understand the dynamics and benefits of the project as an example of public engagement. Our analysis also draws on events and initiatives documented over the course of the project and our own observations as participants in project workshops, events and exhibitions.

Through our immersion in and reflection on the project, we came to understand public and engagement as multiple and complex entities. In an iterative process linking theory and data, we began to consider the extent to which the concepts 'emergent public' and 'assemblage' might help to frame the project in terms of its scope, purpose and implications. We discuss the appropriateness and applicability of these particular conceptual approaches below.

\section{Neoliberalism and a public engagement agenda in higher education}


Understandings of what universities are and what they are for have often centred on the idea of 'public good' (Hazelkorn and Gibson 2017, 3). Yet, conceptions of public good in relation to higher education and the role of knowledge have changed over time and, in the second half of the twentieth century, have been shaped by neoliberal ideas and economics (Williams 2016). In the UK, ${ }^{1}$ marketization and commodification of all aspects of higher education have gone hand in hand with a much closer scrutiny of universities and the development of new mechanisms of accountability, amidst broader mistrust of public sector professionals (Lea 2015, 181). A public engagement agenda in higher education emerged in this context.

Neoliberal ideology, in global ascendancy from the 1970s, advocated reducing the power of collective agencies, giving individuals greater entrepreneurial freedoms and re-establishing the centrality in society of the free market (Jackson 2012, 51). The processes of neo-liberalization included the dismantling of prior institutional frameworks and powers and the withdrawal of the state from areas of social provision (Harvey 2007). In UK universities, the free market model has been promoted through deregulation, privatization and reductions in real terms in levels of public expenditure in higher education. Yet, the rhetoric of deregulation and liberalisation central to neoliberalism masks processes of re-regulation and a tightening of government control. This has been evident in a myriad of ways: from a much more active financial management of universities by governments, through a closer and more regular monitoring of university costs (Radice 2014, 13) to the national assessment of research through the Research Assessment Exercise (RAE) and Research Excellence Framework (REF) and the quality of educational standards and learning, encapsulated in iterations of Quality Assurance Agency (QAA) review procedures from the mid 1990s onwards. Performance indicators were thus used to align universities with the market demands of a global economy (e.g. through surveys of graduate employment) and do so, according to neoliberal arguments, in the interests of public accountability. ${ }^{2}$ This centrally driven transformation of the sector has found local expression in the rolling out of what have been termed 'new public management principles' (Deem et al. 2007). These in turn have created enhanced roles for finance, human resources, marketing and quality departments in higher education institutions, all mirroring best practice from the private sector. ${ }^{3}$ A neoliberal ideology in UK higher education has spawned competition between institutions and amongst employees within an institution, based on a particular definitions and criteria for measuring performance.

Neoliberalism formed as a theory of political economy but has also framed thinking about social life and personhood. Its prevailing theme of enterprise 'provides a rationale for structuring the lives of individual citizens' (Rose 1999, 230). Individuals are expected to be entrepreneurial and responsible in shaping their own lives through making personal choices within a sphere of consumption (Rose 1999). In the neoliberal university, where the market dominates, students are understood to be consumers, purchasing their education via student loans, and knowledge a commodity to be used in a trading relationship within the private sector (Brackman 2015). In this context, public good has come to be understood as the sum of individual (often financial) gains and knowledge is viewed instrumentally as a route to acquiring skills for employability and ensuring the prosperity of individual citizens (Williams 2016, 622, 627). 
The significance of public engagement in the UK can be understood as part of a much longer historical debate on the role and purpose universities and the current context shaped by neoliberal ideas. Against this background, public engagement developed as part of a wider policy agenda directed at encouraging universities to be more accountable and make a vital and valuable contribution to society in the twenty first century. In 2008 the National Coordinating Centre for Public Engagement was established and hosted at the University of the West of England 'as part of a $£ 9.2 \mathrm{~m}$ (four year) project to inspire a culture change in how UK universities engaged with the public' (National Coordinating Centre for Public Engagement). In 2011 a circular from the funding councils required universities to address their social, economic and cultural impact, in order to meet the Research Excellence Framework funding criteria (REF 2011, 5-6). The Research Councils produced a concordat for public engagement with research (UKRI). Moreover, a number of universities established their own public engagement units, for example at the University of Bath in 2012 (University of Bath). An impact agenda, linked with funding for research, configures knowledge as a form of public good in so far as it produces measurable effects on or benefits for culture, society, the economy, the environment, health, public policy, quality of life (REF 2021).

In practice, the term 'public engagement' has come to encapsulate a 'wide range of objectives, approaches and activities' (Burchell 2015, 12) and relationships with various external agencies, private, state and charity. The kinds of good produced for publics varies enormously as does the ways in which 'public' is understood.

Our involvement in the Lost Trades of Islington project alerted us to many and diverse forms of public, engagement and benefit that are not easily measured. We sought to investigate such elements by inviting participants to reflect on their experiences of taking part in the project. Our examination of spoken and written accounts, our observations and project documentation suggested that the concepts 'emergent public' and 'assemblage' might be useful tools in exploring the dynamics of the project and its various nuanced effects.

\section{Conceptualising publics and engagements}

Mahony and Stephanson (2017) distinguish between calculative, normative and emergent understandings of 'the public'. The calculative perspective views the public as a pre-existing entity that can be spoken for and understood, for example, through polls and surveys. The normative perspective focuses on the public's role and capacities in relation to the ideals of democracy and publics are defined and mobilized around values. This form at least allows scope for publics to be targeted and resisted on ideological grounds rather than simply engaged with via some neutral or objective process. The emergent perspective views publics as constituted entities that are 'that are made and enacted through dynamic processes of mediation' and 'called into existence through different modes of address' $(2017,40)$. 
An emergent perspective encapsulates Michael Warner's argument that publics do not exist apart from the discourses that address them and that discourse can also enable the formation of self-organising counterpublics (Warner 2002, 72). In turn, discourses are underpinned by ideological positions (Buckley 2018). Publics are also called into being through discursively constituted lines of demarcation, which exclude as well as include (Butler 2015, 4-6). As Butler points out, demarcation makes some groups recognizable and others unrecognizable (4-6). Further, 'none of us acts without the conditions to act', which are also produced through discourse (Butler 2015, 16).

Our analysis of participants' interactions, reflections and activities over the course of the project led us to think of publics as multiple and emergent. They led us to understand forms of engagement as multiple, complex, evolving and changing. We adopted the term 'assemblage' (Deleuze and Guattari 1987) to capture and describe the multiple elements, qualities, dynamics, fluidity, affects and relations constituting publics and engagement activities at different moments over the duration of the Lost Trades project. Assemblage provides a framework for understanding how different elements of public engagement coalesced, gained momentum and changed at specific times under specific conditions. Such conditions include the obligations of the neoliberal university and a public engagement discourse. They also include an expanding interest in oral history as a method of inquiry and a means of recovering the past, specifically the 'hidden histories' of marginalized groups and communities (Thomson 2008).

\section{Assembling the Lost Trades project and its publics}

We were approached by a charity worker (Andrea) at Age UK Islington, a local charity reliant in part on local authority funding, who had been leading reminiscence groups with older residents. She had been impressed by the stories people told about their working lives and, given the marked physical and social transformation of the locality, decided that these should be recorded. ${ }^{4}$ Andrea invited us together with the archivist at Islington History Centre to be partners in an oral history project focused on working lives in Islington. She secured funding for the project from the National Lottery Heritage Fund (NLHF) and became the project coordinator.

Practically, the project's objectives were to: collect oral histories from men and women who had worked in industries and trades that have subsequently declined or disappeared; deliver a series of workshops for both older volunteers living in Islington and students, teaching them to conduct interviews and carry out background archival research; organise poetry and photographic workshops for another group of older Islington volunteers; and use sound recordings, photographs, poems in a series of exhibitions engaging a wider audience with the project. The relevance of oral history (both as a discipline and a movement) to the project, lay in its commitment to 'give voice' to some of those excluded from official histories (Bornat et al. 2019; Ritchie 2015, 5; Lynd 1993). 
Students and older volunteers together attended workshops on oral history interviewing and archival research and interviewed older residents in pairs. Volunteers participating in the photographic workshop produced portraits of the interviewees and, in some instances, photographed them outside their old place of work. Summaries of the interview transcripts formed the basis of the poetry workshop for volunteers. The sound recordings, photographs, poems and a selection of artefacts relating to the various occupations, formed the basis of exhibitions at the University (November 2018), Islington's History Service (November 2018February 2019) and Drovers community centre in Islington. A further group of students designed and made boxes to house the audio equipment used for playing interview excerpts in the exhibitions.

Those willing to be interviewed for the project (six women and four men, born between 1924 and 1948) either used a local Age UK community centre or were known to service users or replied to advertisements in local newsletters and on organisation websites. Interviewees had worked in a mix of occupations and discussed work during the period 1936-1994. Ten older volunteers were recruited from existing groups at the community centre and six students were recruited from undergraduate courses in health and social care, media and communications and film and television studies to conduct the interviews. ${ }^{5}$ Four of the six students took part in the Lost Trades project as part of a core module 'Work Related Learning', intended to 'develop employability skills and competencies' and 'facilitate the transition into graduate level employment'. The module combines a series of taught classes (focused on developing workrelated learning and critical reflection skills) with project work opportunities provided in conjunction with external employers and organizations. The remaining two students hoped to use the project as part of their final year dissertation.

In an earlier paper, we discussed the older interviewees' reflections on their past work and neighbourhoods (Gabriel and Harding 2020). In this paper, we discuss interviews (conducted in 2019) with the project organiser, interviewees and students and student coursework from the work-related learning module (submitted in 2018). In interview and coursework, individuals were invited to reflect on their experiences of participating in the project. This material was collected after the interviews had been conducted and after exhibitions had taken place. We use this data to examine 1) the publics and engagements (assemblages) and 2) benefits or public good created through the project.

The project addressed, and brought into being, several publics: a broader group of community centre users who were invited to take part in the project; those who agreed to speak about their working lives in interview; volunteer interviewers; student interviewers; students involved in exhibition design and organisation; those who visited the exhibition at different sites; staff from AgeUK Islington, London Metropolitan University, Islington History Centre, and finally those who have subsequently heard or read about the project. These were not discrete and uniform publics as the different groups mentioned came together and interacted in workshops on: interviewing and archival research (volunteer interviewers, students, university staff, archivist, charity worker); interviews (interviewees, volunteer interviewers and students), and exhibitions (project participants, organisers, visitors). ${ }^{6}$ Different publics were called into 
existence through invitations to participate in different activities. Such publics were also discursively constituted by lines of demarcation which excluded as well as included: those who did not get to tell their stories and those who did not become interviewers, possibly because they did not hear the call to participate or because they lacked confidence and/or time. These publics formed, mixed and reformed over the course of the project in particular relations and activities, guided by particular ideas, practices and motivations, in different locations, using various technologies. Assemblage captures the constitution of different publics and engagement activities, their dynamic and fluid qualities, at particular moments, over the course of the project.

Engagement centred on practices of reflection: Andrea reflecting on the stories told in the reminiscence group; interviewees reflecting on aspects of their working lives and neighbourhoods; students and volunteers reflecting on archival materials, interview questions and responses; students, interviewees and the project organiser reflecting on their involvement in the project after the exhibitions. We are interested in how participants thought through and rethought experiences. We suggest that such practices of reflection can be seen as constituting practices of criticality and something that benefitted all participants - a form of public good. Previously, we discussed how older Islington residents reflected on past experiences of work and neighbourhood from the position of the present, in a way that was critical of both past and present (Gabriel and Harding 2020). In this article, we consider how such practices of criticality benefited narrators and enhanced students' learning. Here, we understand the idea of criticality to involve a questioning approach to learning (Friere and Faundez 1989) and active engagement with and refection on previously held knowledge and/or self-reflections. We are interested in how students' participation in the project challenged their ways of thinking and/or prompted new (to them) understandings (Healy et al. 2015, 150).

\section{Older narrators as publics}

Those who spoke about their past working lives in Islington were addressed and brought into existence as a public by discourses advocating the benefits of autobiographical storytelling to the individual and wider publics. Andrea articulated such views in reflecting both on her motivations for initiating the project and on how older residents had benefited. The idea for the project emerged from an already existing regular weekly reminiscence group where people often spoke about their working lives. Andrea recalled thinking that there 'wonderful stories to capture' especially considering 'the way Islington had changed'. The broader historical discursive context included an oral history movement which emphasizes the value of individual memories, particularly those of marginalised people, as part of recovering aspects of the past which would otherwise be unknown. Andrea also reflected on the benefits to the broader social group of community users of listening to others speaking about their lives, observing that reminiscence groups had engendered understanding and respect across between people from different cultural backgrounds and, to some extent, countered racism. 
Andrea: And I think it is really good to remind people that actually you have a lot in common even though you look very different and you seem to have come from very different places, there actually still all these similarities: maybe sort of experiences of poverty in different ways, experiences of hard times with the family. ${ }^{7}$

The relational aspects of storytelling - organizing and putting into words experience that is listened to by an audience - were clearly significant. Reflecting on the benefit to individuals interviewed in the project, Andrea said that it made them it made them feel 'that their stories are valuable and that makes them feel valuable and respected'. Most important was the experience of 'being listened to'.

Andrea: ... they told me that it made them feel very proud seeing their stories up on the wall ..seeing the photos and actually and yes just that idea that some people's stories were never told before. And also some people just hadn't had that much attention .. so it was actually just even the attention apart from actually the finished product and everything. So just actually having someone taking an individual interest for an hour! And so to have someone, two people, listening with great interest for an hour was significant as well for some people. Actually, if you think how often somebody just listens to you for an hour, it's actually very rare. And so, that's kind of a nice part of the process.

The project interviews included some people, not others. Participation in the project formalized storytelling - through the presences of interviewers, interview questions, and sound recording narrating experience and created new audiences in interviewers, and exhibition visitors as stories were re-presented for public display. The importance of being of interest to others and being listened to was also articulated by those interviewed after the final exhibition. They conveyed both a sense of surprise that people, particularly younger people, would be interested in their working lives and a sense of satisfaction and pride, a renewed sense of identity, both individual and collective.

Stanley (former coach builder): I found it was a lot of people didn't understand what was lost trades and when they did find out about me, Stanley Wilson, they were so interested they didn't want to leave me...I feel great to let people see who I was and know what kind of person doing that kind of trade even the lord mayor come there and he was amazing he was so interested in what we were doing.

Eunice (handbag maker): Well, I enjoyed it very much and I was very surprised that something like that developed you know because after so many years you think that people wouldn't $t$ be interested but people did become very interested but even a few weeks back I had to describe everything from the scrap of the bag to how we came to finish it off. ${ }^{8}$

Such responses indicate the value and significance attached to social relations and exchanges with other older volunteers and younger people by interviewees. That their knowledge, 
expertise and experience were of genuine interest to interviewers and those attending the exhibitions, including the mayor, was both affirming and emotionally fulfilling. Public displays of reflections on their working lives in the exhibitions, subsequently deposited in the local archives, conferred official recognition of their contribution to the history of the borough.

Through the project design and discourses foregrounding the importance of oral history, narrators were discursively created as an expressive and reflective public. This public was also an assemblage consisting of interviewers (co-producers of the narratives through questioning and active listening), ideas, locations, recoding technologies, feelings, motivations. The stories and invitations to interpret them brought further publics into being: participating in photography and poetry workshops; constructing and organising the exhibitions; visiting the exhibitions at different sites (the university, Islington Library/History Service, Drovers Community Centre); and those users of Drovers who, after seeing the exhibition, wanted to tell their stories. These publics and practices of engagement were assemblages comprising different groups of people, ideas, places, technologies for recording, editing and displaying spoken accounts and images, practices of reflection and storytelling.

Older residents reflected critically on their experiences in interview (Gabriel and Harding, 2020). Those listening in the reminiscence group (although not part of the project) engaged critically and some (according to Andrea) revised their assumptions and evaluations of others and shifted towards mutual understanding and respect. Those who saw the exhibition recognised the value of storytelling and some wanted to participate in this after the project.

\section{Student participants as publics}

Students were a public directly addressed and constituted by a neoliberal discourse outlining the need to be entrepreneurial and responsible in shaping their own lives and to acquire skills that contribute to their employability (Williams 2016, 622, 627). Specifically, the work-related learning module created a terrain and imperative in which to act and engage in learning in contexts (workplaces and organizations) beyond the university. The design and processes of the project and the learning objectives set by the module required them to be self-reflexive in relation to their activities.

As students engaged with the aims and activities of the Lost Trades project they moved beyond the university into new (physical, social and emotional) spaces and became a part of other publics. Various public engagement assemblages - energetic mixes of encounters, relations, ideas, sites, emotions and feelings - in which students participated, as they prepared for and conducted interviews with older Islington residents, incorporated opportunities for critical thinking and learning. We examine two examples of criticality in students' reports of their experience of participating in the project and ways in which they felt challenged. The first concerns challenges to taken for granted assumptions and knowledge about the world. The second concerns social and emotional challenges. 
Students reported gaining new knowledge about workplaces, working practices in the past and understanding of how these had changed, including the loss of specific trades and types of employment. In Pearl's case, critical engagement focused on employment rights and particularly those concerned with health and safety, which she had taken for granted previously but now understood to be a relatively recent area of industrial relations reform post-dating the work experiences of those she interviewed. Aaruni's visit to the local history service to conduct background research prior to her interview and the interview itself provided opportunities for reflecting on similar issues and development of skills in communication.

Aaruni: At the History Centre, I learnt about the different sources of historical information on the working lives of people. I found out about employee rights, how they had to work overtime because they weren't getting paid enough.....I was interested to learn how young she (Dolly) was when she started working- 14 years old I think.... I found the range of jobs interesting and the Borough feels very different now to the way people described it, more factories, poorer, friendlier..... It taught me how to talk to people from different age ranges, what they were interested in (and) what they wanted to talk about. ${ }^{9}$

An important feature of critical thinking is the capacity to challenge taken for granted assumptions about the world. Aaruni gained a sense of working conditions in the middle of the twentieth century (1936-46), which challenged her assumptions about the nature of work. She was able to make connections between individual problems and the social context in which they are embedded, in much the same way that C.W. Mills articulated the promise of sociology as its ability to forge links between personal troubles and public issues (Mills 2000). Similarly, the process of engaging with the past, challenging assumptions and filling gaps in selfknowledge, is integral to critical thinking. This resonates with Henry Giroux's idea that, 'history in this sense is engaged as a narrative open to critical dialogue rather than predefined text to be memorized and accepted unquestioningly' $(2010,717)$. Meetings and conversations between students and other publics (older volunteer interviewers, interviewees) drew on the experiences of those who lived through a period of significant social and economic change in the locality and this formed a basis for generating knowledge about the past and gaining a critical perspective on the present.

The project invited students to leave the classroom and embark on a series of new encounters that most found challenging. Describing his experience of the first project meeting with partners and older volunteers, Xanti said: 'I felt instantly an outsider'. He went on to say that he waited observing quietly and gradually felt more relaxed to the extent that: 'I crossed my comfort zone'.

Xanti: The milieu seemed unfamiliar for me at some points. I had never volunteered in a charity project, nor had I ever heard of many of the trades that were discussed prior to the interviews. Two main focuses that I would argue, marked a limit that I needed to cross to leave my comfort zone and engage fully into the learning experience. The large group of volunteers involves students - from different courses and different ages - and 
Age UK volunteers - older residents of Islington, some born in the borough and some not. All of us, coming from different backgrounds and life stories, such as the traders we would interview. I would argue, a very interesting experience but very new to me, therefore it needed my full involvement and commitment to what was needed from me. ${ }^{10}$

Like Xanti, several other students explicitly mentioned moving out of their 'comfort zone' - a relational and emotional space - in order to negotiate difference, participate and learn. That is, new social encounters, relations of difference and feelings of (temporary) discomfort provided grounds for acquiring new knowledge, as students reflected on previously held assumptions and their sense of self. Students' main role was interviewing and they reflected on the importance of preparation in not only in intellectual (background research) but also in emotional and relational terms: they mentioned the importance of 'creating the right atmosphere' and 'building trust' (Xanti).

Xanti illustrates how a critical perspective on film-making arose from both technical skills acquired elsewhere on his course and social relations developed on the project. In his report, he reflects on his (practical) learning experience as a film student and wanting to film aspects of the Lost Trades project. This was a personal goal and, he writes, his determination to achieve it 'enhanced my learning experience and resulted in the creation of a new opportunity instead of a missed opportunity'. However, the process of negotiating permission to make a film entailed engaging with and talking to participants, a new source of learning for him and took him beyond the technical aspects of film-making.

Xanti: By talking to them about it, I realised that I was already learning more than I thought. I was learning about filming, as making a documentary involves not just learning camera angles and a different way of storytelling than in fictional films, but it also means engaging others with your ideas, something I started to learn at the time, as there are no actors in this project, only real people telling their own real stories. ${ }^{11}$

Students reflected specifically on working with a volunteer and how generational difference contributed to their learning and new understandings. Pearl said that she got on well with the older volunteer interviewers and particularly appreciated their love of history and experience. She thought that the questions they suggested for interview were especially pertinent, stimulating memories and new understandings, because they related to shared (with the interviewee) experience of historical time.

Xanti described how he and Phoebe, the older volunteer he was paired with, had very different ways of working, how this worked positively and how they gave each other feedback. His new understanding of the contribution of volunteers was a source of inspiration that led him to reflect on his own aspirations for his media practice.

Xanti: I have been amazed about Phoebe's commitment to the project, having volunteered for many years and assisting Age UK to help others, all done under no 
external pressure but her own decision to actively participate. I would argue that working with volunteers, provided me as a student with a different experience of doing things and contributing with your actions, something I would argue a filmmaker does when cinema goes beyond entertainment. As a film student, I would expect my work to provide that contributive action. ${ }^{12}$

In the Lost Trades project, social relations, encounters and emotions together formed a basis for developing both practical and critical knowledge. Student coursework and its requirement for critical reflection further enhanced a process of reflexivity. Xanti reflected on Bould and Walker's (1990) discussion of the 'act of noticing' and 'becoming aware' and remarked that this was enhanced by reflecting on experience through the process of writing a diary of the experience and keeping field notes. He wrote that his learning was not bounded by the project and continued through reflection on experience well after the project had ended.

\section{Discussion}

We have reflected on the 'The Lost Trades of Islington' project (completed in 2019) in relation to debates about public engagement and the neoliberalization of higher education. The project encompassed a plurality of engagement activities and 'emergent publics', which we framed as assemblages. We have argued that assemblage helps to capture the many different forms of engagement and formations of publics, their dynamism and fluidity, their physical, social, cognitive and affective elements. Assemblage encapsulates the sense that publics and engagements were not discrete or static entities but rather were made, unmade and remade over the course of the project through a variety of exchanges. Yet, the terms assemblage and emergent publics are limited when it comes to accounting for the conditions that give rise to, sustain, marginalise or even extinguish particular publics. Indeed, the project highlights the need to acknowledge the discursive/ideological context and the conditions in which social hierarchies are challenged and/or constituted through public engagement. That is, particular public engagement assemblages are constituted in particular discursive and ideological contexts and are capable of both reproducing and contesting existing relations of power. Here, Warner's notion of counterpublics (2002) is potentially useful in so far as it highlights the significance of power relations and the role of dominant and oppositional discourses (we discuss counterpublics below).

We adopted an understanding of public as an emergent entity called into existence through discursive modes of address, whilst emphasizing that such processes exclude as well as include. This understanding echoes Judith Butler's notion of the 'public' as a wager for hegemony that can serve to naturalise forms of exclusion (Butler 2015, 4-5). The Lost Trades project challenged some forms of exclusion through valorising working-class histories and fostering intergenerational relations and understandings. Other forms of exclusion such as poverty Islington has the fourth highest rate income deprivation amongst older people of any local authority in England (London Borough of Islington 2019a) - could not be tackled. Clearly, the Lost Trades project created discursive conditions for acting for some individuals and not others. 
In the project, different assemblages were made possible and encouraged by a neoliberal discourse, emphasising market relations and enterprise, with knowledge seen as a means to measurable ends. It invited students to perform as enterprising subjects, entering new situations, gaining new skills and knowledge, and working on self through reflective practices. Yet, the Lost Trades project created assemblages that produced other less tangible and measurable goods: relational, affective, critical, political (challenging hierarchies between the subjects and objects of knowledge). The project enabled older narrators to gain a sense of selfworth through autobiographical narratives and through relations with other older volunteers, exhibition participants and critically though their relations with students. It enabled students to encounter new learning environments and develop criticality. Indeed, we argued that a key benefit (a kind of good) to different publics created through the project consisted in practices of criticality - understood as also relational and affective - whereby individuals reflect on experience and develop new (to them) understandings.

The project invited students to engage with older people living in Islington, creating a learning environment in which their preconceptions were challenged and new understandings and respect for older working-class residents fostered. Students were encouraged to adopt critical approaches to education and 'to realize their potential to contest injustice through courageous knowledge acts' (Zepke 2015: 696). Insofar as this was achieved, and there was evidence of this above, it served to break 'the connection between neoliberalism and engagement' (Zepke $2015,700)$. 'Performativity' in neoliberalism values what is 'produced, observed, measured recorded and reported' (Zepke 2015, 695), but the performative features of a neoliberal university were to some extent re-framed to 'enable engagement for social justice in higher education' (Zepke 2015, 700). One of the ways, such re-framing took place was to 'use the creative capacities within disciplines to seek alternative pathways and to use alternative pathways inside and outside the academy to converse and interact with others' (Zepke 2015, 700). Student participants on the project, through their encounters with diverse engagement assemblages, gained new knowledges about workplace practices, health and safety, industrial relations and in Xanti's case critical documentary film practice. They also learned through a series of social and emotional challenges associated with their relations with older volunteers. In particular, the project encouraged them to value such intergenerational exchanges and the understandings derived from older people's knowledge and experiences. The observations made above illustrate how differently positioned project participants engaged with counterhegemonic discourses (foregrounding equality and social justice) through the project.

To what extent might the many benefits to participants outlined above be could considered the outcomes of the successful creation of a counterpublic? To an extent, the term counterpublic, captures the ideological and oppositional character of the project. The overriding goal of the Lost Trades project - to collect, archive, exhibit and appreciate the previously untold stories of local working-class residents - united participants around the values of promoting social justice and respect through dialogue. A potential counterpublic inhered in relations and affective investments generated through participation in joint activities: oral history workshops, researching archival material, planning meetings, and the production and consumption of 
individual narratives. However, Warner's definition of counterpublic (2002) arguably implies greater coherence, self-organisation and sustainability than we observed in the Lost Trades project. Overall, therefore, the project's positive (though hard to measure) effects alongside its ephemerality place it in an uneasy relation to the neoliberal university.

Public engagement projects come and go and we cannot know how the various benefits gained will survive beyond the life of the project. But, we do know that the borough now has a permanent record of these histories. We also know that the university's senior leadership has publicly recognised the worth of the project, recognising it as part of a wider equity and social justice strategy and has subsequently used the exhibition stands at student applicant open days. In other words, some of the counterpublic values driving the Lost Trades project may well be carried forward to future projects.

Despite the gains outlined above, including participants' engagement with counter-hegemonic discourses, neoliberalism was all too evident in the project in a number of ways. Firstly, it was hard to avoid the market orientation which appears a recurrent feature of public engagement initiatives. An important motive and precondition for such projects is the scope they provide for accessing new income streams. In this case, the alliance between the charity history service and the university did generate additional funding from the National Lottery Heritage Fund but the small grant restricted the scale of the project. Moreover, the logistics of running a collaborative project ensured that staff from all three partner organisations contributed over and above their workloads. The work experiences of participants from all three organisations resonate with Dave Hill's analysis the changing role of academic labour, that is the pressure to do more for less and reduce staff costs through income generation (2008).

Secondly, as we discussed above, the project was shoehorned into what was considered the most convenient module to accommodate it, the work-based learning module. Of course, such modules have become commonplace in British universities and seen as an important tool delivering good employment outcomes, regarded as a key performance indicator and very much associated with the neoliberal paradigm. Whilst the module offered more flexibility in terms of content and delivery than other modules, it also meant there was less space for critical reading and discussion than there might have been in modules such as the sociology of work, social change in the city, etc. Whilst students demonstrated an awareness of changes in workplace practices and in the urban environment the work-based assessment requirements did not require students to demonstrate such levels of understanding nor was there time on the module to develop these ideas in any depth. Moreover, projects by definition are short lived and whilst there are many recurrent practices in higher education, projects have a built-in timeframe which ensures their ephemerality and that of their publics.

\section{Conclusions}

The Drovers Centre, whose users comprised predominantly local, working class residents of mixed backgrounds, many of whom had attended the Centre over a number of years, closed in 2020 (London Borough of Islington 2019b). Its closure lends weight to the precariousness 
associated with an assemblage or an 'emergent public'. But the reason for its demise is of greater significance. This was precipitated by the local authority's decision to cease funding, which in turn had been necessitated by central government austerity measures. At the same time, AgeUK Islington also chose to change direction, away from community activities with less tangible outputs to a more individualised approach with performance indicators and measurable outputs. In this sense neoliberalism prevailed, but not before, as we have argued some important gains were made in the pursuit of public good. In particular the project fostered a critical relationship to learning and community amongst its student participants and valorised subjects (older participants) who might otherwise have been overlooked and undervalued.

The broader historical, ideological and power context in which the project took place includes recognising both the neoliberalization of the university and the existence of deep-rooted inequalities and social injustices in contemporary society. Some publics are more precarious more marginal, invisible and harder to reach - than others (Bucklaschuk 2014). Older people may well fall into that category, particularly those whose status has been called into question through migration, as well as those whose lives are characterised by social isolation and/or restricted autonomy in institutional care or whose experience is unrepresented in the mainstream media. In this sense assemblages and emergent publics proved helpful in grasping the idea of ephemeral publics. The project called into existence a public consisting of older people whose working lives were recalled, represented, acknowledged and valued and who were changed by the process. In this sense, the project can be said to have worked both against neoliberalism and within it. The capacity for critical learning and valorised working-class identities served the public good, and indeed left a legacy both material and less tangible, as discussed above, yet ultimately proved both a marginal and short-lived initiative, as the particular publics it called into being, were always at the mercy of more powerful forces.

\section{References}

Bornat, J., R. Perks and P. Thomson. 2019. "The life history of Oral History from editors' memories of its origins and developments". Oral History Journal @50 1969-2019, 9-23. https://www.ohs.org.uk/journal/ohj-50/

Bould, D. and D. Walker. 1990. "Making the most of experience." Studies in Continuing Education, 12 (2): 61-80.

Bucklaschuk, J., 2014. "Precarious Publics: Interrogating a Public Sociology for Migrant Workers in Canada." In The Public Sociology Debate, edited by A. Hanemaayer and C. J. Schneider, 10813. Vancouver: University of British Columbia.

Buckley, A. 2018. "The ideology of student engagement research." Teaching in Higher Education 23, (6): 718-732.

Burchell, K. 2015. Factors affecting public engagement by researchers: literature review. Policy Studies Institute, London. 
Butler, J. 2015. Notes Toward a Performative Theory of Assembly. London: Harvard University Press.

Deem, R., Hillyard, S., and M. Reed. 2007. Knowledge, Higher Education, and the New Managerialism: The Changing Management of UK Universities. Oxford: Oxford University Press.

Deleuze, G., and F. Guattari. 1987. A Thousand Plateaus. Capitalism and Schizophrenia. Minneapolis: University of Minnesota Press.

Freire, P., and A. Faundez. 1989. Learning to Question; a pedagogy for liberation. New York: Continuum.

Gabriel, J. 2008. "Refugee Community Oral Histories: issues in pedagogy and curriculum development." Teaching in Higher Education, 13 (3): 265-277

Gabriel, J. and J. Harding. 2020. "Reimagining Islington: work, memory, place and emotion in a community oral history project." Oral History, 48 (2): 43-56.

Giroux, H. 2010. "Rethinking Education as the Practice of Freedom: Paulo Freire and the promise of critical pedagogy." Policy Futures in Education, 8 (6): 715-21.

Harding, J. 2002. "Talking about Homelessness: a teaching and research initiative in East London." Teaching in Higher Education, 7 (1): 81-95.

Harding, J. 2014. "Looking for trouble: exploring emotion, memory and public sociology." Oral History, 42 (2): 94-104.

Harding, J. and J. Gabriel. 2004. "Communities in the Making: Pedagogic Explorations using Oral History." International Studies in the Sociology of Education, 14 (3): 185-201.

Harvey, D. 2007. A Brief History of Neoliberalism, Oxford: OUP.

Hazelkorn, E. and A. Gibson. 2017. "Public goods and public policy: what is public good, and who and what decides?" Working paper no. 18. London: Centre for Global Higher Education, UCL Institute of Education.

Healey, M., C. Bovill and A. Jenkins, A. 2015. "Students as Partners in Learning." In Enhancing Learning and Teaching in Higher Education: engaging with the dimensions of practice, edited by J. Lea, 141-172. Maidenhead: Open University.

Jackson, B. 2012. "The think-tank archipelago: Thatcherism and neo-liberalism." In Making Thatcher's Britain, edited by B. Jackson and R. Saunders, 43-61. Cambridge: Cambridge University Press. 
Lea, J. 2015. "The landscape of higher education". In Enhancing Learning and Teaching in Higher Education: engaging with the dimensions of practice, edited by J. Lea, 173-197.

Maidenhead: Open University.

London Borough of Islington, 2019a. Deprivation. https://www.islington.gov.uk/about-thecouncil/islington-evidence-and-statistics/islingtons-population-evidence-and-

statistics/deprivation

London Borough of Islington, 2019b. 'Report of Executive Member for Health and Adult Social Care'.

https://democracy.islington.gov.uk/documents/s19812/Drovers\%20Centre\%20Exec\%20Report \%200ct\%202017.pdf.

Lynd, S. 1993. "Oral History from Below", Oral History Review 21 (1): 1-8.

Mahony, N. and H.C. Stephansen. 2017. "Engaging with the public in public engagement with research." Research for All, 1 (1): 35-51.

Maisuria, A and M. Cole. 2017. "The neoliberalization of higher education in England: An alternative is". Policy Futures in Education, 15 (5): 602-619.

Mills, C.W. 2000. The Sociological Imagination. Oxford: OUP.

National Coordinating Centre for Public Engagement. https://www.publicengagement.ac.uk/

Radice, Hugo. 1. 2013 "How We Got Here: UK Higher Education under Neoliberalism." ACME: An International Journal for Critical Geographies, 12 (2): 407-18. https://www.acmejournal.org/index.php/acme/article/view/969.

REF. 2011. Decisions on Assessing Research Impact. REF 01.2011.

https://www.ref.ac.uk/2014/media/ref/content/pub/decisionsonassessingresearchimpact/01 11.pdf

REF 2021. Research Excellence Framework: Index of revisions to the 'Guidance on submissions' (2019/01), https://www.ref.ac.uk/media/1447/ref-2019 01-guidance-on-submissions.pdf p66 Ritchie, D. 2015. Doing Oral History. Oxford: OUP

Rose, N. 1999. Governing the Soul: The Shaping of the Private Self. London and New York: Free association Books.

Thomson, A. 2008. "Oral History and Community History in Britain: Personal and Critical Reflections on Twenty-Five Years of Continuity and Change." Oral History, 32 (1): 95-104. 
UKRI. n.d. Concordat for Engaging the Public with Research: a set of principles drawn up by the Funders of Research in the UK.

https://www.ukri.org/files/legacy/scisoc/concordatforengagingthepublicwithresearch-pdf/ Williams, J. 2016. "A critical exploration of changing definitions of public good in relation to higher education." Studies in Higher Education, 41 (4): 619-630.

University of Bath n.d. Public Engagement Unit. https://www.bath.ac.uk/professionalservices/public-engagement-unit/

Warner, M. 2002. Publics and Counterpublics. New York: Zone Books.

Zepke, N. 2015. "What future for student engagement in neo-liberal times?" Higher Education, 69: 693-704.

\footnotetext{
${ }^{1}$ The choice of UK, Britain or England to frame what follows is problematic, as government and higher education policies and practices in particular vary in their scope and reach. The following examples are indicative: Research Excellence (UK); Student Fees (charged in three countries but not in Scotland). The National Coordinating Centre for Public Engagement (UK); the Office for Students (England). We have chosen to use the UK in part because of the impact of neoliberalism has been felt in all four countries and in part for convenience, but it is important to acknowledge significant divergences as well as commonalities between the four nations.

${ }^{2}$ The idea that such metrics as achievement rates student satisfaction teaching quality has been widely critiqued (See: Maisuira and Cole 2017).

${ }^{3}$ This relates to the practice of employing senior staff from the private sector whilst valorising their lack of experience of higher education

${ }^{4}$ We had previously met with Andrea to discuss possible ways of working together - charity and university staff, older people and students.

${ }^{5}$ In subsequent discussion, the names of older volunteers and participants from Age-UK Islington have been kept in accordance with the preferences of those interviewed. The names of students have been anonymized.

${ }^{6}$ Other publics were constituted through the poetry and photographic workshops but are not discussed in this paper.

${ }^{7}$ Andrea interviewed by Jenny Harding and John Gabriel, 2 August 2019.

${ }^{8}$ Interview with Stanley Wilson and Eunice Braithwaite by John Gabriel, 24 July 2019.

${ }^{9}$ Aaruni interviewed by John Gabriel, 11 September 2019.

${ }^{10}$ Cited from coursework submitted in January 2018.

${ }^{11}$ Cited from coursework submitted in January 2018.

${ }^{12}$ Cited from coursework submitted in January 2018.
} 